ANDREJA BRAJŠA ŽGANEC*

andreja.brajsa.zganec@pilar.hr

RENATA FRANC ${ }^{*}$

renata.franc@pilar.hr

LJILJANA KALITERNA LIPOVČAN*

Ijiljana.kaliterna@pilar.hr

IVAN DEVIĆ*

ivan.devic@pilar.hr

MAJA TADIĆ VUJČIĆ

maja.tadic@pilar.hr

TONI BABAROVIĆ*

toni.babarovic@pilar.hr

*Institut društvenih znanosti Ivo Pilar
Primljeno: 09. 10. 2019.

Prihvaćeno: 16. 10. 2019.

DOI: $10.21857 / \mathrm{mnlqgc0p6y}$

\title{
SUDJELOVANJE DJECE I MLADIH U ISTRAŽIVANJU DOBROBITI: KVALITATIVNA ANALIZA
}

Projekt razvoja kohortnog longitudinalnog istraživanja (ECDP) EuroCohort, financiran u okviru OBZOR 2020 (HORIZON 2020) programa Europske komisije, ima cilj razviti konkretne modele nove europske istraživačke infrastrukture za koordinaciju budućeg velikog europskog kohortnog 25-godišnjeg longitudinalnog istraživanja o dobrobiti djece i mladih. Cilj jedne dionice projekta je oformiti savjetodavnu grupu djece (CYPAG) te kroz radionice i fokusne grupe utvrditi dječju perspektivu o dobrobiti, što im znači riječ "dobrobit", kao i njihovo razumijevanje etičkih pitanja u longitudinalnim istraživanjima dobrobiti djece. $S$ dvadesetak djece, starosti od 10 do 15 godina, održane su tri fokusne grupe. 


\section{UVOD}

Interes za dobrobit djece i mladih sve je više prisutan $u$ istraživanjima $u$ društvenim znanostima a povećao se u posljednje vrijeme s porastom literature koja pokušava identificirati, opisati, analizirati i nadgledati dobrobit djece i mladih (npr. Dinisman, Fernandes i Main, 2015.; Fattore, Mason i Watson, 2012; Richardson i Ali 2014). Dobrobit djece je multidimenzionalni konstrukt koji obuhvaća kognitivnu, bihevioralnu i emocionalnu regulaciju, socijalnu kompetenciju te indikatore subjektivne dobrobiti, na koje se u posljednje vrijeme stavlja sve veći naglasak u istraživanjima (npr. Ben-Arieh, Casas, Frønes i Korbin, 2014; Bradshaw, Hoelscher i Richardson, 2007; Moore, Murphey, Beltz, Martin, Bartlett i Caal, 2016; Newland, 2015). Dobrobit djece definira se kvalitetom života i odnosima s neposrednim izvorima socijalizacije djece u djetinjstvu te je osim za razvoj djece važna i za društvo u cjelini. Podatke o objektivnim indikatorima dobrobiti i razvojnim ishodima djece najčešće su davali roditelji, skrbnici i drugi relevantni stručnjaci (učitelji, odgojitelji, socijalni radnici) i institucije u ime djece dok se u novije vrijeme sve više pitaju sama djeca o vlastitoj dobrobiti (Bradford, Rutherford i John, 2002; Casas i González-Carrasco, 2018.; Franc, Sučić, Babarović, Brajša-Žganec, Kaliterna-Lipovčan i Dević, 2018; González-Carrasco, Casas, Malo, Vinas, i Dinisman, 2017.; Tadić Vujčić, Brajša-Žganec i Franc, 2019.).

Bradshaw i suradnici (2007) definiraju dječju dobrobit koristeći 51 indikator koje grupiraju u 8 kategorija (materijalna situacija, smještaj, zdravlje, obrazovanje, subjektivna dobrobit, veze s drugima, sigurnost, građansko sudjelovanje) dok Ben-Arieh i suradnici (2014) definiraju tri perspektive dječje dobrobiti koje je potrebno obuhvatiti istraživanjima: 1) uvjete života djece i objektivne mjere dobrobiti; 2) subjektivne procjene dobrobiti djece; 3) percepcije i vrednovanje dječjih ishoda od strane drugih važnih osoba u životu djece poput roditelja, učitelja i ostalih stručnjaka. Subjektivna dobrobit odnosi se na način na koji pojedinci vrednuju svoje živote ili koliko povoljno procjenjuju vlastiti život (Diener, 2012). Konstrukt subjektivne dobrobiti sastoji se od kognitivnih procjena kao što je zadovoljstvo životom i zadovoljstvo pojedinim domenama života te emocionalnih procjena poput pozitivnih i negativnih emocija (Diener, 2013). U istraživanjima subjektivne dobrobiti djece ispituje se zadovoljstvo životom općenito, ali i zadovoljstvo različitim domenama života, zadovoljstvo školom, obitelji, odnosima s vršnjacima, slobodnim vremenom i životnim okruženjem (Huebner, 2004). U ovakvim istraživanjima pokazuje se da nešto više od $70 \%$ djece izjavljuje da su većinom zadovoljni svojim životima (Huebner, Drane i Valois, 2000; Park i Huebner, 2005). Subjektivna dobrobit djece važan je prediktor pozitivnih 
ishoda djece te zaštitni faktor od stresnih okolinskih utjecaja i razvoja psihičkih poremećaja (Proctor, Linley i Maltby, 2009; Suldo i Huebner, 2004a). Istraživanja pokazuju brojne pozitivne veze subjektivne dobrobiti djece i adolescenata s različitim pozitivnim ishodima poput višeg samopoštovanja i internalnog lokusa kontrole (Huebner, 1991), više percipirane kontrole i socijalne podrške (Casas, Figuer, González, Malo, Alsinet i Subarroca, 2007; Suldo i Huebner, 2004b) i manje rizičnog ponašanja (Shek, 2005). Što se tiče prediktora dječje subjektivne dobrobiti, istraživanja upućuju na to da su odnosi s obitelji i vršnjacima, te zadovoljstvo školom i susjedstvom neki od snažnijih prediktora (Lawler, Newland, Giger, Roh i Brockevelt, 2017). U jednom istraživanju se pokazalo da djeca u dobi od 10 do 15 godina koja procjenjuju svoju subjektivnu dobrobit visokom tu dobrobit povezuju najčešće s odnosima u obitelji i ne govore o problemima, dok djeca koja svoju subjektivnu dobrobit procjenjuju niskom povezuju dobrobit najčešće s odnosima s vršnjacima i problemima (Navarro, Montserrat, Malo, González, i Crous, 2017).

Kvalitativni pristup danas je sve više prisutan u društvenim istraživanjima pa su tako kvalitativna istraživanja sve zastupljenija i u području istraživanja dječjeg razvoja. U kvalitativnim istraživanjima u društvenim znanostima kao dominantne metode koriste se intervjui i fokusne grupe u skladu s ciljevima postavljenih istraživanja (Ajduković, 2014; Milas, 2005.). Kvalitativni pristup posebno je pogodan za istraživanja u razvojnoj psihologiji i istraživanju pojedinih domena razvoja jer su djeca posebna skupina ispitanika i prikupljanje podataka je potrebno prilagoditi dobi djeteta. Kvalitativni pristup omogućuje bolje razumijevanje različitih pozitivnih doživljaja djece i mladih kao i dobivanje boljeg uvida u različite poteškoće u razvoju djece i mladih te je posebno pogodan za dobivanje podataka i razumijevanje fenomena u dječjem razvoju koji se otežano prikupljaju uobičajenim kvantitativnim metodama istraživanja.

Dodatni segment $u$ istraživanjima je uključivanje djece i mladih kao aktivnih sudionika u osmišljavanju istraživanja, posebno longitudinalnih s djecom i mladima (Ozan, Pollock, Goswami i Lynn, 2018). Naime, postoji širok spektar pristupa u uključivanju djece u istraživanja, od onih gdje se djeca smatraju objektima istraživanja, do onih u kojima djeca imaju središnju ulogu. Sve veći interes za provođenjem istraživanja s djecom nalazi se u pretpostavci da su djeca socijalni akteri koji imaju pravo biti saslušani te da se treba uvažavati njihovo mišljenje i u kontekstu znanstvenih istraživanja (Cassas, González, Navarro i Aligué, 2013). U praksi još uvijek postoje brojne nejasnoće vezane uz ulogu koju djeca mogu imati u istraživanjima te koje mjesto zauzimaju djeca u odnosu na odrasle istraživače. Postoji više modela kako djecu i mlade uključiti u istraživanje. To su dobivanje 
ANDREJA BRAJŠA ŽGANEC i surad.: Sudjelovanje djece i mladih u istraživanju dobrobiti: kvalitativna analiza

podataka od djece i mladih, konzultiranje s djecom i mladima o istraživanju, suradnja s djecom i mladima o provođenju istraživanja te da djeca i mladi preuzimaju aktivnu ulogu u istraživanju (Shaw, Brady i Davey 2011). Djeca i mladi mogu prema Hartu (1992) biti uključeni u osam razina, od najnižih gdje oni nisu aktivni sudionici do najviše, gdje djeca i mladi zajednički odlučuju s istraživačima. Šest koraka za uključivanje djece u istraživanje su sposobnost uključivanja, znanje i vještine, razvoj etičkog protokola i procesa istraživanja, odabir prikladnih metoda istraživanja, izgradnja povjerenja i dobrih odnosa, odabir prikladnih načina komunikacije s različitim medijima te fleksibilnost u različitim kontekstima, kulturnim, političkim i institucionalnim koji utječu na način na koji ljudi rade $s$ djecom i koje metode odabiru (Johnson, Hart i Colwell, 2014). Jedna od preporuka u analizi dječje participacije u Republici Hrvatskoj koja govori o uvažavanju, uključivanju i prihvaćanju djece je organizirati zainteresirane skupine istraživača koji rade s djecom kao sudionicima i kao predmetima njihovih istraživanja. Te grupe trebale bi razgovarati o temama poput sudjelovanja djece u istraživanju, specifičnosti njihove perspektive i specifičnosti istraživanja s djecom, posebno istraživanja koja sudjelovanje uzimaju kao temu odnosno pristup (Jeđud Borić, Mirosavljević i Šalinović, 2017). Jedan od zadataka projekta razvoja kohortnog longitudinalnog istraživanja (ECDP) upravo je istražiti mogućnosti uključivanja djece i mladih u buduće veliko europsko longitudinalno istraživanje o dobrobiti djece i mladih. Projekt razvoja kohortnog longitudinalnog istraživanja (ECDP) EuroCohort $^{1}$, financiran u okviru OBZOR 2020 (HORIZON 2020) programa Europske Komisije, ima cilj razviti konkretne modele nove europske istraživačke infrastrukture za koordinaciju budućeg velikog europskog kohortnog 25-godišnjeg longitudinalnog istraživanja o dobrobiti djece i mladih. Ovakvo istraživanje usmjereno je na praćenje skupine djece i mladih kroz duži niz godina čime bi se osiguralo niz pokazatelja o zdravlju i dobrobiti djece i mladih, kao što je npr. stres u školi ili osjećaj sreće i zadovoljstva u obiteljskom okruženju, a omogućilo bi izravnu usporedbu podataka iz različitih europskih zemalja kao i razumijevanje kako na dobrobit djece i mladih utječu društveni kontekst i različite okoline. Takvi podaci omogućili bi pozitivan utjecaj na dobrobit djece i mladih pri čemu je važno uključivanje same djece $u$ istraživanje. Uključivanje djece u osmišljavanje i provedbu budućeg istraživanja kroz izravne konzultacije s djecom omogućuje poštivanje prava djece i mladih da izraze svoje mišljenje o odlukama koje ih se tiču te osigurava određenu razinu zajedničke izrade studije: stručnjaci i djeca i mladi. Uklju-

1 Projekt razvoja kohortnog longitudinalnog istraživanja (ECDP) EuroCohort financiran je u okviru OBZOR 2020 programa Europske Komisije - ugovor broj 777449. 
čivanje djece i mladih važno je kako bi djeca i mladi ljudi imali formalnu ulogu u razvoju istraživanja s djecom, kako bi se djeca i mladi detaljnije informirali o projektu te kako bi stručnjaci dobili povratne informacije od djece i mladih o dobrobiti, etici, načinu prikupljanja podataka u istraživanju i slično.

\section{CILJ}

Opći cilj rada je iz dječje perspektive sagledati mogućnost istraživanja dobrobiti djece uzevši u obzir etička načela o sudjelovanju djece u istraživanjima. Specifični ciljevi su: ispitati važnost različitih područja dobrobiti iz perspektive djece, ispitati mišljenja djece o davanju pristanka na sudjelovanje u istraživanju dobrobiti i etičke dileme vezane uz dobivanje pristanka te ispitati mišljenja djece o privatnosti i zaštiti osobnih podataka prilikom provođenja znanstvenih istraživanja.

\section{METODA}

\section{Sudionici i postupak}

Istraživanje je provedeno u sklopu projekta ECDP (eng. European Cohort Development Project) čiju hrvatsku dionicu provodi Institut društvenih znanosti Ivo Pilar. Cilj projekta je razvoj nove europske istraživačke infrastrukture za koordinaciju i provedbu prvog velikog europskog longitudinalnog istraživanja praćenja dobrobiti djece i mladih pod nazivom EuroCohort dok je cilj jedne dionice projekta, čiji su rezultati prikazani u ovom radu, bio oformiti savjetodavnu grupu djece (CYPAG) te kroz radionice/ fokusne grupe utvrditi dječju perspektivu o dobrobiti, kao i njihovo razumijevanje etičkih pitanja u longitudinalnim istraživanjima dobrobiti djece. Cilj cijelog ECDP projekta usmjeren je na uspostavljanje uspješne istraživačke infrastrukture i budućeg EuroCohort istraživanja kroz: (a) razvijanje podrške među ključnim donositeljima politika te nacionalnim agencijama zaduženima za financiranje istraživačkih infrastruktura i anketnih prikupljanja podataka; (b) razvijanje znanstveno izvrsnog nacrta budućeg longitudinalnog anketnog istraživanja; te (c) uspostavljanje stabilnog operativnog okvira koji jamči logističku opstojnost budućeg EuroCohort istraživanja.

Ukupno su provedene tri radionice/fokusne grupe s 20 učenika (14 ženskog spola) u jednoj osnovnoj školi u Varaždinu u dobi između 10 i 15 godina u prvoj radionici. Sve tri radionice održane su sa istim učenicima, u školi u Varaždinu u učionici koja je posebno pripremljena za provedbu istraživanja. Ispitivanje je provedeno u popodnevnim satima nakon održane redovne nastave. Svaka radio- 
nica/ fokusna grupa trajala je do 4 školska sata sa dvije do tri pauze od 15 minuta ovisno o potrebama sudionika. Prilikom provođenja fokusne grupe jedan istraživač je vodio raspravu, drugi je pomagao u dijeljenju radnih materijala, provjeravao jesu li sudionici dobro razumjeli uputu prilikom radnih zadataka i sl., dok je treći istraživač bilježio odgovore na za to unaprijed pripremljenom obrascu za odgovore. Za prikupljanje podataka korišteno je i audio snimanje.

Sudionici su odabrani u suradnji s nacionalnim i lokalno relevantnim organizacijama, dječjim školskim odborima, relevantnim nevladinim organizacijama te sportskim udruženjima. Pri izboru sudionika vodilo se računa da skupina bude što je više moguće heterogena. Od 20 sudionika, njih 12 bili su: djeca iz manjinskih skupina $(\mathrm{N}=3)$, djeca iz razvedenih brakova $(\mathrm{N}=3)$, djeca iz jednoroditeljskih obitelji ( $N=2)$, djeca s kroničnim zdravstvenim poteškoćama ( $N=2)$, djeca koji žive u siromaštvu $(\mathrm{N}=2)$. Za vrijeme odvijanja radionica djeca su dio vremena bila podijeljena u tri grupe prema potrebama scenarija prikupljanja podataka. Prva radionica održana je u svibnju 2018. te je na njoj sudjelovalo ukupno 20 učenika. Druga radionica održana je u listopadu 2018. s 19 sudionika dok je treća održana u veljači 2019. s ukupno 18 sudionika. Do osipanja sudionika u zadnjoj radionici došlo je zbog izvanškolskih obveza. Svaki sudionik je na kraju svake radionice dobio malu nagradu za sudjelovanje u vrijednosti 100 kuna. Fokusne grupe vodila su tri iskusna istraživača s Instituta društvenih znanosti Ivo Pilar koji sudjeluju u projektu ECDP.

Istraživanje je provedeno prema načelima Etičkog kodeksa istraživanja s djecom (Ajduković i Kolesarić, 2003), Etičkog kodeksa Hrvatske psihološke komore, (Hrvatska psihološka komora, 2004) strukovnih etičkih kodeksa, te drugih važećih zakona i propisa Republike Hrvatske i u skladu sa svim etički standardima istraživanja koja uključuju djecu i mlade (Coyne 2010; Skånfors 2009), a odobrilo ga je Etičko povjerenstvo Instituta društvenih znanosti Ivo Pilar, kao i Etičko povjerenstvo Manchester Metropolitan Sveučilišta koje je koordinirajuća ustanova za cijeli projekt. Prije samog provođenja istraživanja dobivena je dozvola od nadležnog Ministarstva i dozvola ravnatelja škole u čijim prostorima se provodilo istraživanje. Od roditelja je zatražena i dobivena pisana suglasnost za sudjelovanje njihovog djeteta $u$ istraživanju. Učenici su pisanim putem bili informirani o istraživanju prije sudjelovanja. Obrazac s informiranim pristankom uključivao je informacije o: svrsi i ciljevima istraživanja, tipu pitanja koja će biti postavljana i načinu provođenja istraživanja, povjerljivosti danih kontakt podataka i odgovora, načinu pohrane podataka, prezentaciji podataka na razini skupine i uporabi podataka samo u znanstvene svrhe. Također, učenici su informirani da ne moraju odgovoriti na bilo koje pitanje koje im izaziva nelagodu ili neugodu, te da u bilo 
kojem trenutku mogu odustati od sudjelovanja u istraživanju bez ikakvih posljedica. Sudionici su bili upozoreni da u skladu s Općom uredbom o zaštiti podataka (GDPR) u svakom trenutku mogu zatražiti uvid u svoje podatke, kao i njihovo brisanje.

\section{Scenarij prikupljanja podataka}

Fokusne grupe su vođene prema unaprijed pripremljenom protokolu s jasno određenim temama i ciljevima. Tijekom sve tri radionice bilo je sudionicima naglašeno da ne postoje točni i netočni odgovori, poticalo ih se da raspravljaju, uspoređuju, daju primjere, i objašnjavaju. Dobiveni nalazi u svakoj prethodnoj fokusnoj grupi, prezentirani su sudionicima fokusnih skupina u idućoj radionici te su sudionici imali mogućnost dati svoj osvrt na prethodnu radionicu i dobivene rezultate.

Scenarij prve radionice s djecom i mladima na temu dobrobit sastojao se od tri dijela. U prvom dijelu predstavljeni su istraživači, projekt i proces odvijanja radionice, te su sudionici ispunjavali upitnik o sociodemografskim podacima. U drugom dijelu sa sudionicima se raspravljalo o konceptu dobrobiti, općem razumijevanju i mjerenju dobrobiti, definicijama dobrobiti, značenju dobrobiti za učenike, glavnim područjima (obitelj, škola, okoliš, zdravlje, materijalne stvari...), ulozi odnosa u obitelji za njihovu dobrobit (roditelji, braće/sestre), ulozi njihove škole (nastavnici, prijatelji), ulozi njihova mjesta/susjedstva, njihova zdravlja, stambenih uvjeta. Zatim se raspravljalo o sreći, pozitivnim i negativnim osjećajima, trenutnim osjećajima sreće, spokoja, užitka, zabave kao i trenutnim osjećajima tuge, anksioznosti, ljutnje, usamljenosti, o općem osjećaju zadovoljstva životom, te o psihološkoj dobrobiti koja podrazumijeva autonomiju, osobni razvoj, samoprihvaćanje, smisao života, upravljanje okolinom te pozitivne odnose s drugima. Od sudionika je traženo da ispričaju svoju priču o dobrobiti. Zatim ih se pitalo za mišljenje o stupnju u kojem se u društvu čuje njihov glas, njihovoj spremnosti sudjelovanja u istraživanjima dobrobiti te što bi sve prema njihovom mišljenju trebalo pitati djecu i mlade vezano uz dobrobit. U trećem dijelu sudionici su zamoljeni da nacrtaju što je za njih dobrobit te su mogli postaviti pitanja o temama o kojima se do tada nije raspravljalo.

Scenarij druge radionice s djecom i mladima na temu dječjih prava i zaštite privatnosti sastojao se također od tri dijela. Sudionicima su postavljena pitanja o njihovim pravima i zaštiti podataka, o informiranom pristanku za sudjelovanje $\mathrm{u}$ istraživanju i pitanja o kontekstu ispitivanja u istraživanju. U uvodnom dijelu raspravljalo se o budućem longitudinalnom istraživanju dobrobiti te se tražilo 
ANDREJA BRAJŠA ŽGANEC i surad.: Sudjelovanje djece i mladih u istraživanju dobrobiti: kvalitativna analiza

od sudionika da razmisle o mogućoj koristi i važnosti takvog istraživanja za njih i drugu djecu i mlade u Hrvatskoj i u Europi. U drugom dijelu sa sudionicima je raspravljano o privatnosti, sigurnosti, pohrani i korištenju podataka. Sudionicima su postavljena pitanja o privatnosti i njenoj važnosti, o pravima djece i mladih u kontekstu sudjelovanja u istraživanjima, o informiranom pristanku, iskrenosti djece kada daju odgovore na pitanja prilikom sudjelovanja u istraživanju te je traženo mišljenje o postojanju nekih stvari i pitanja koja su toliko privatna da ih ne bi trebalo uopće postavljati djeci u istraživanjima. Zatim su sudionici pitani o važnosti istraživanja dobrobiti, o načinu na koji bi najradije željeli sudjelovati u istraživanju, o mišljenju vezno za traženje suglasnosti od roditelja za sudjelovanje $u$ istraživanju. Sudionike se pitalo i o temama o kojima ne bi željeli razgovarati u prisutnosti roditelja/učitelja/vršaka, nagradama za sudjelovanje u istraživanju te načinima prezentacije prikupljenih podataka. U završnom dijelu sudionici su raspravljali pod kojim uvjetima bi oni i njihovi vršnjaci sudjelovali u longitudinalnom istraživanju djece kao što je EuroCohort.

Scenarij treće radionice s djecom i mladima na temu dobrobiti i etičkih pitanja sastojao se također od tri dijela. U uvodnom dijelu provedene su sa sudionicima dvije vježbe na temu dobrobiti u kojima se tražilo od sudionika da daju pisane povratne informacije. U prvoj vježbi sudionicima je podijeljen upitnik gdje su navedena neka područja/ teme koje bi mogle biti važne za dobrobit. Za svako područje učenici su trebali označiti koliko je to za njih važno ( 0 = nije važno, a 10 = izrazito važno). Po završetku vježbe svi zajedno su kratko prodiskutirati dobivene odgovore. U drugoj vježbi sudionici su ponuđene domene dobrobiti trebali označiti rednim brojevima od 1 do 3 s obzirom na važnost te su po završetku vježbe ponovno svi zajedno prokomentirali odgovore. U drugom dijelu provedena je rasprava sa sudionicima na temu etičkih pitanja i sudjelovanja djece u istraživanjima. Prikazan je obrazac za pristanak na sudjelovanje u istraživanju te se od sudionika tražilo mišljenje i eventualni prijedlozi za poboljšanje. Zatim se sa sudionicima raspravljalo o etičkim pitanjima, tvrdnjama vezanim za sudjelovanje djece u istraživanjima. Raspravljalo se o tvrdnjama iz Etičkog kodeksa istraživanja s djecom (Ajduković i Kolesarić, 2003). U završnom dijelu radionice od sudionika se tražilo mišljenje o diseminacijskom videu o projektu EuroCohort i njegovim mogućim poboljšanjima. Na kraju su sudionici zamoljeni da nešto kažu o svojoj ulozi u sve tri radionice te da povratne informacije daju putem kratkih video zapisa koje su u parovima snimali na kraju radionice.

Nakon prikupljanja podataka u sve tri radionice audio zapisi fokusnih grupa su transkribirani te su dodane sve relevantne napomene i zapažanja zabilježena tijekom pojedine radionice. Podaci o pojedinim sudionicima su anonimizirani 
tako da su sudionicima dodijeljeni brojevi od 1 do 20. Tako anonimizirani podaci onemogućuju reidentifikaciju. Kod analiziranja podataka slijedili smo postupak analize kvalitativnih podataka od prikupljanja podataka, transkripcije, upoznavanja s podacima, kodiranja i analiziranja do tumačenja prikupljenih podataka (Gale i sur. 2013; Rabiee 2004; Ritchie i Lewis 2003). Nakon prikupljanja podataka, saželi smo prepisane podatke, te ih analizirali prema slučaju i po šifri. U sljedećoj fazi izdvojene su zanimljive izjave relevantne za odgovore na postavljeni cilj istraživanja te smo napravili interpretaciju sumiranih odgovara. U narednom poglavlju prikazujemo dio prikupljenih rezultata u sve tri radionice prema postavljenim ciljevima rada i po pojedinim tema.

\section{REZULTATI}

Dobiveni rezultati pružaju dublji uvid u načine doživljavanja dobrobiti i istraživanja dobrobiti iz perspektive djece i mladih, te su prikazani po pojedinim temama kako bi se odgovorilo na postavljeni cilj istraživanja. Prvo je prikazana važnost pojedinih domena dobrobiti za djecu i mlade, zatim mišljenje djece i mladih o pravima djece i mladih koji sudjeluju u istraživanjima te o etičnosti i zaštititi podataka. Tipične izjave sudionika za pojedine teme su prikazane u tri poglavlja.

\section{a) Važnost pojedinih domena dobrobiti (1. i 3. radionica)}

Rezultati provedene fokusne grupe pokazuju da djeca (sudionici „S“) razumiju značenje dobrobiti na način da definiraju dobrobit kroz pozitivne događaje iz vlastitog života odnosno kroz ono što ih čini sretnima.

Pokazalo se da djeca mogu samostalno identificirati nekoliko važnih područja povezanih s dobrobiti. $U$ prvom redu dobrobiti i sreću povezuju s pozitivnim osjećajima, a također razumiju da negativni osjećaji mogu biti povezani s manjom dobrobiti.

"Sretan/a sam kada nema stresa" (19S)

„Djeca su tužna kada nemaju prijatelja niti podršku, kada su uvijek sama za sebe" (10S)

"Osjećamo se loše kad nas drugi vrijeđaju“ (2S)

„Ono što djecu čini manje sretnima su svađe i pritisak, nedostatak podrške i loši odnosi s vršnjacima." (20S)

"Loše osjećaje stvara kad nismo u dobrim odnosima s drugima" (15S)

"Osjećam se napeto i pod stresom zbog ocjena u školi unazad nekoliko dana zbog završetka školske godine" (17S) 
S dobrobiti povezuju dobre odnose kod kuće, odnose s roditeljima te braćom i sestrama. Također navode školu kao ključnu za dobrobit, jer može utjecati na povećanje, ali i smanjenje sreće i zadovoljstva, a važnim smatraju i mogućnost korištenja slobodnog vremena. Tako na primjer navode:

„Sretnom/im me čini kad sam u dobrim odnosima sa cijelom obitelji, kada nemam stresa i kada je dobro u školi" (9S)

„Kada se posvađam kod kuće sa svojima, s mamom i tatom odmah sam lošije kad izađem van ili kad dođem u školu i odmah sam lošije volje" (3S)

"Škola zna biti stresna, pogotovo neki predmeti su stresni" (13S)

"Kad si s ekipom možeš se opustiti i biti ono što jesi" (17S)

"Druženje s ekipom stvara osjećaj slobode, to je kao druga obitelj"(4S)

Osim toga, važnim za dobrobit smatraju i odnose s vršnjacima a pogotovo prijatelje koje vide kao izvor pozitivnih emocija ali i mogući izvor socijalne podrške kada podrška odraslih izostane. Tako na primjer navode:

„Prijatelji su jako važni, kad sam s prijateljima sam opušten i sretan" (5S)

„Ponekad je dobro imati prijatelja jer on kuži kako se osjećamo i može nam puno pomoći" (6S)

„Nekada nas veliki ne mogu shvatiti a djeca nekada mogu puno pomoći"(1S)

Kako bi se obuhvatila i druga područja dobrobiti koje djeca nisu spontano navela, a također mogu biti važna za dobrobit, u okviru treće radionica je provedeno i kratko kvantitativno istraživanje. Pritom je korišten kratak upitnik s ponuđenim 21 područjem koja su se u ranijim istraživanjima pokazala važnim za dobrobit. Koristeći skalu od 1 do 10 (1- najmanje važno do 10 - najviše važno) zadatak sudionika je bio procijeniti važnost svakog od 21 ponuđena područja (grafički prikaz 1 ). Iz prosječnih procjena važnosti za svako područje može se zaključiti da djeca gotovo sva područja smatraju važnim (za sva područja osim jednog dobivene su prosječne ocjene iznad rezultata pet, koji predstavlja teorijsku srednju vrijednost skale). Pritom su u prosjeku najvažnijima procijenjeni (ocjena devet ili više): obitelj $(M=9,79)$, prijatelji $(M=9,76)$, zaštita od zlostavljanja $(M=9,65)$, životno zadovoljstvo $(M=9,29)$, sreća/nesreća $(M=9,29)$, prava djece $(M=9,12)$ te škola $(M=9,00)$. Područja koja su od ponuđenih najmanje važna (ocjena manje od 6) te time i djeci se čine manje povezana s dobrobiti su: mjesto stanovanja $(M=5,47)$, obiteljski novac $(M=5,47)$, ljutnja $(M=5,24)$, siromaštvo $(M=5,12)$, korištenje računala $(M=5,06)$ te društvene mreže $(M=4,82)$. 


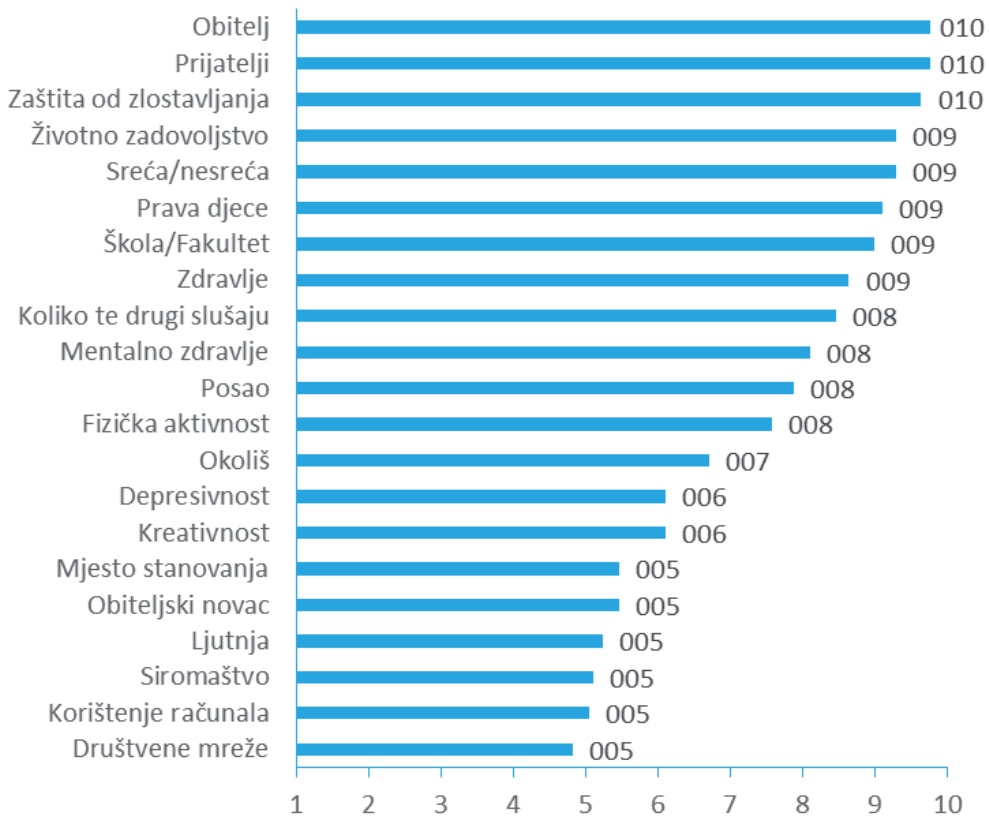

Grafički prikaz 1: Važnost pojedinih područja za dobrobiti djece i mladih (procjene od 1- 'najmanje važno' do 10 - 'najviše važno')

U provedenom istraživanju fokus je bio ne samo na različitim životnim područjima nego i na širim dimenzijama dobrobiti. Sudionici ( $N=17)$ su u sklopu iste radionice između šest ponuđenih dimenzija trebali rangirati tri koje smatraju najvažnijim dimenzijama dobrobiti. Prethodno im je objašnjeno značenje svake dimenzije: fizička dobrobit (zdravstveno stanje, kvaliteta života povezana sa zdravljem, fizičke vještine i sposobnosti, vježbanje, trening, sport, slika o vlastitom tijelu), psihološka dobrobit (zadovoljstvo životom, ljutnja, zabrinutost, tuga, sreća, samopouzdanje, stres, zaštita od zlostavljanja), socijalna dobrobit (odnosi s vršnjacima i prijateljima, obiteljski odnosi, usamljenost, dostupnost školovanja i edukacija, zaposlenost i nezaposlenost, migracije), kognitivna dobrobit (stavovi o odrastanju, školi i radu, autonomiji u životu, uvažavanje, dječja prava), bihevioralna dobrobit (devijantno ponašanje, hiperaktivnost, nasilničko ponašanje, sudjelovanje), materijalna dobrobit (obiteljska financijska situacija, stanovanje, bogatstvo, siromaštvo, okoliš i ekologija). Dimenziji koju su smatrali najvažnijom trebali su dodijeliti rang 1 , nešto manje važnoj rang 2 te najmanje važnoj od odabrane prve tri trebali su dodijeliti rang 3. (rezultati su rekodirani radi lakše 
interpretacije na način da prvi rang donosi 3 boda, drugi rang donosi 2 boda te treći rang nosi 1 bod). Između psihološke, socijalne, fizičke, kognitivne, bihevioralne te materijalne dobrobiti, sudionici najvažnijim smatraju fizičku, psihološku te socijalnu dimenziju dobrobiti. Manje važnim smatraju kognitivnu, materijalnu i bihevioralnu dimenziju dobrobiti (Grafički prikaz 2).

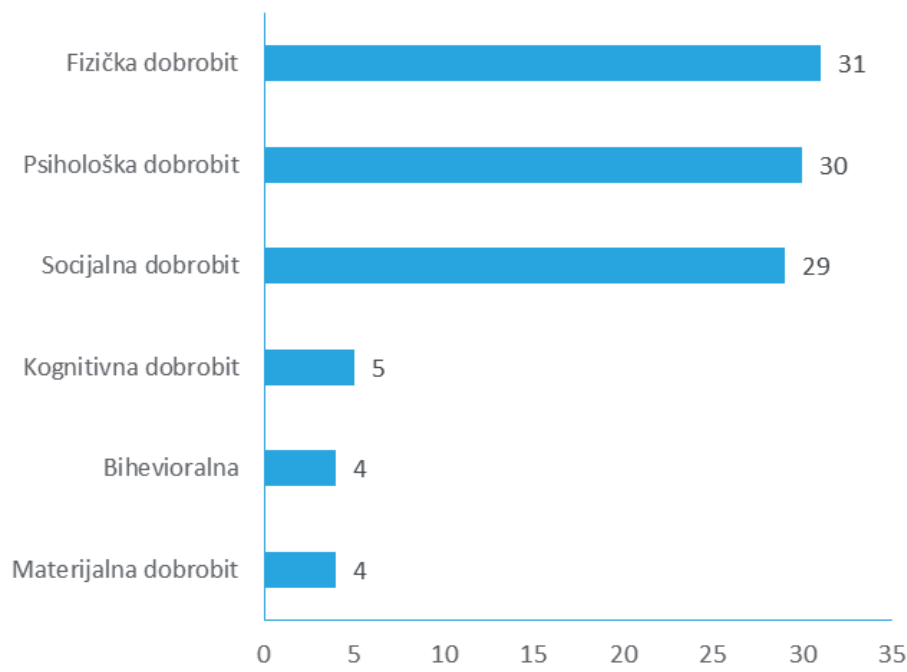

Grafički prikaz 2: Važnost pojedinih dimenzija dobrobiti (procjene od 1 - 'najmanje važno' do 3 - 'najviše važno').

Sudionici su samostalno naveli još nekoliko specifičnih područja koja smatraju važnima a koja prema njihovom mišljenju nisu dovoljno istaknuta među ponuđenim područjima dobrobiti, kao što su: odnos prema samome sebi, stav prema radu, odnos s profesorima, vrijeme provedeno u školi, ocjene, fizički izgled, slobodno vrijeme/hobiji te jednakost i ravnopravnost. Kao glavne domene dobrobiti navode:

a) odnose kod kuće "kada se posvađam kod kuće sa svojima, nismo dobro" (2S) b) odnose $s$ braćom i sestrama „odnosi s braćom i sestrama mogu i umanjiti i povećati sreću, kako kada"(8S) c) školu "škola zna biti stresna i sve što učiteljica traži od nas ali većinom je ok" (11S) „ک̌kola zna biti stresna, pogotovo neki predmeti su stresni“ (6S) 
d) slobodno vrijeme

"košarka", "nogomet", "rukomet", "sport je važan za sreću“ (7S)

e) prijatelje

„prijatelji su jako važni“, „Da, prijatelji su puno, puno važni“ (10S)

\section{b) Pristanak na sudjelovanje u istraživanju (2. i 3. radionica)}

Sudionici navode da nemaju dovoljno znanja o pravima djece i mladih koji sudjeluju u istraživanjima što je vidljivo i u sljedećim izjavama;

"Nismo svjesni prava koje imamo" (12S)

"Mislim da je važno da se djeci istaknu njihova prava" (14S)

"Nisam znao/ znala da od istraživanja mogu odustati u bilo kojem trenutku" (16S)

Što se tiče obrasca za dobivanje pristanka za sudjelovanje u istraživanju, djeca i mladi razumiju važnost informiranog pristanka te također razumiju značenja povjerljivosti i anonimnosti u istraživanju. Smatraju da je informirani pristanak iznimno važan te da je nužno potreban da bi se istraživanje moglo provesti.

"Povjerljivost znači da našim podacima ne može pristupiti nitko bez našeg pristanka" (18S)

"Anonimnost znači da naša imena nisu poznata drugima" (6S)

Sudionici se slažu da bi istraživači trebali najprije pitati roditelje mogu li njihova djeca sudjelovati u znanstvenom istraživanju. U slučaju da žele sudjelovati, a roditelji ne žele dati pristanak, djeca bi pokušala uvjeriti svoje roditelja da daju pristanak.

"Ovisi o temi istraživanja ali ponekad bi roditelji trebali poslušati i što mi mislimo" (14S)

"Roditelji bi se mogli ljutiti no možemo pokušati razgovarati s njima i pokušati ih uvjeriti da daju dozvole da sudjelujemo" (5S)

Općenito se može zaključiti da se djeci sviđa ideja da se njih osobno pita za pristanak.

"To je dobra stvar, jer se nas pita za mišljenje" (2S)

"Kada me se pita za mišljenje osjećam se odgovorno, imam osjećaj da me se želi čuti i da se moje mišljenje uvažava" (8S)

"Osjećam se uzbuđeno, važno, odraslo i sretno ali me također malo strah da ne postupim pogrešno" (9S)

"Dobro se osjećam" (17S) 
Sa sudionicima treće fokusne grupe raspravljano je o tri važna etička pitanja vezana uz sudjelovanje djece $u$ istraživanju. Zadatak sudionika bio je napisati slažu li se s 3 etička principa vezana uz davanje pristanka za sudjelovanje u znanstvenom istraživanju iz Kodeksa etike istraživanja s djecom (Ajduković i Kolesarić, 2003):

Za dijete do 14 godina pisani ili usmeni pristanak daje roditelj.

Traženo je mišljenje sudionika o ovom pitanju, koliko smatraju važnim da za dijete do 14 godina pisani ili usmeni pristanak daje roditelj. Tipični odgovori sudionika su slijedeći:

"Slažem se da bi djeca do 14 godina trebala pristanak roditelja"(10S)

„Mislim da je to dobro i slažem se s tim jer neka djeca ne mogu uvijek sama donositi pravilne odluke"(6S)

„Slažem se ali mislim i da bi djeca sama trebala dobiti na odabir da ona sama odaberu hoće li sudjelovati ili ne"(4S)

"Slažem se time da roditelji pisanim pristankom potvrde sudjelovanje"(15S)

"Treba pristanak oboje ali krajnja odluka bi trebala biti na djetetu"(10S)

„Mislim da bi pisani ili usmeni pristanak roditelja trebalo tražiti do šesnaeste godine"(7S)

Dijete starije od 14 godina samo daje pisani ili usmeni pristanak.

Sudionicima je postavljeno pitanje što misle o tome da dijete starije od 14 godina samo daje pisani ili usmeni pristanak, može li dijete starije od 14 godina samo donijeti odluku o tome hoće li sudjelovati ili ne? Tipični odgovori sudionika su slijedeći:

"Mislim da bi mladi mogli svoj pristanak davati sami, bez roditelja samo kada su stariji od 16 godina"(2S)

"Dijete bi moglo samo davati pristanak, ali uz obveznu konzultaciju ili razgovor s roditeljima ili skrbnikom."(6S)

"Smatram da bi dijete sa 16 godina moglo samostalno davati suglasnost."(15S)

"Dijete od 14 godina samo može dati pristanakjer je postalo odgovorno"(16S)

"Možda, mislim da bi djeca od 16 godina mogla dati pristanak bez pristanka roditelja, ali ne djeca od 14 godina."(4S)

"Mislim da je bolje da dijete ne može samo dati pristanak prije 18. godine zato što je bolje da se i roditelji slože s tim"(11S)

"Ne slažem se, mislim da uz pristanak djeteta treba pristanak i roditelja"(14S)

"Ovisi o čemu je dijete dužno dati svoj pristanka, u vezi ozbiljnijih stvari treba potpis roditelja"(9S) 
„Potreban pristanak roditelja do 18 godina jer su u tom razdoblju djeca u pubertetu"(1S)

Djetetu starijem od 7 godina, a koje nije navršilo 14 godina, mora biti objašnjenja svrha i način provođenja istraživanja u skladu s njegovom zrelošću.

Pitali smo djecu što misle o tome. Tipični odgovori sudionika su slijedeći:

„Slažem se jer djeci u dobi 7-14 godina možda neke stvari u istraživanju nisu jasne."(9S)

„Da, mislim da bi trebalo objasniti te prilagoditi objašnjenje o sudjelovanju u istraživanju."(16S)

„Da, djetetu se treba objasniti u čemu sudjeluje."(5S)

"Svakako bi trebalo objasniti i to ne samo djeci u dobi 7-14 godina nego svakome tko sudjeluje u istraživanju."(10S)

„Djeca trebaju biti informiranio istraživanju u skladu sa svojom zrelošću."(8S)

„Da, slažem se, mislim da bi u projektu djeca mogla biti uključena kao i svi stariji, ali bi mogli pitati za objašnjenje stvari koje ne razumiju."(2S)

Zaključno, sudionici razumiju važnost osobnog pristanka te se uglavnom slažu da istraživači trebaju pitati roditelje o sudjelovanju njihovog djeteta u istraživanju najčešće do njegove 16 godine.

\section{c) Privatnost/ zaštita podataka (2. i 3. radionica)}

Sudionici se slažu da je privatnost nešto što je svakome važna te da o privatnosti treba posebno voditi računa.

"Zaštita privatnosti je vrlo vrlo važna" (12S)

Sudionici se s pojmom privatnosti i zaštite podataka susreću najčešće u kontekstu mobilne komunikacije te su stoga njihove slobodne asocijacije na pojam privatnosti; "mobilni telefon", "SMS poruke", i „privatnost u komunikaciji“. Pokazalo se da sudionici imaju nešto više negativnih asocijacija na privatnost nego pozitivnih. Naime, zadatak sudionika je bio da napišu pozitivne i negativne asocijacije na pojam privatnosti. U Tablici 1 su prikazane riječi koje su za sudionike pozitivno ili negativno povezane s privatnošću. 
ANDREJA BRAJŠA ŽGANEC i surad.: Sudjelovanje djece i mladih u istraživanju dobrobiti: kvalitativna analiza

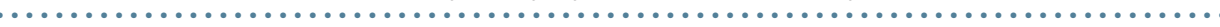

Tablica 1: Prikaz pozitivnih i negativnih asocijacija na pojam privatnosti

\begin{tabular}{ll}
\hline \multicolumn{1}{c}{ Pozitivne asocijacije } & \multicolumn{1}{c}{ Negativne asocijacije } \\
\hline Ti odlučuješ kome ćeš nešto privatno reći & Strah \\
Razgovori s našim vršnjacima & Roditelji \\
Poruke & Sram \\
Društvene mreže & Usamljenost \\
Sigurnost & Izoliranost \\
Zaštita osobnih podataka & Sve držiš u sebi \\
Povjerenje & Sram da netko ne sazna \\
Tajne & Stresni događaji \\
Sloboda & Nesigurnost \\
Jedinstvo & \\
\hline
\end{tabular}

U pogledu sudjelovanja u istraživanju, sudionici daju nekoliko sugestija kako zaštititi privatnost sudionika nekog istraživanja. Sudionici sugeriraju da postoje određena područja o kojima ne bi htjeli razgovarati u istraživanju. Navode na primjer:

"Bilo bi dobro kad bi u istraživanju imali mogućnost izbora da o nekim temama ne razgovaramo" (7S)

"Ne bih htio/htjela razgovarati o odnosu svojih roditelja "(11S)

"O socioekonomskom statusu moje obitelji ne bih razgovarao/la"(5S)

"Postoje stvari o kojima ne bih razgovarao/la, a to mogu biti različite stvari ovisno o tome koje značenje to ima za nas"(9S)

"O rođacima ne bih razgovarao/la" (12S)

"O bolestima"(14S)

Sudionici sugeriraju da bi zbog zaštite privatnosti bilo dobro da tijekom istraživanja razgovaraju samo s jednom osobom ili da odgovore bilježe na unaprijed pripremljeni upitnik i da pri tome imaju mogućnost preskočiti neka pitanja.

"Bilo bi dobro da možemo određena pitanja preskočiti prilikom odgovaranja"(13S)

"Ako bi to bio intervju, bilo bi dobro da razgovaramo samo s jednom osobom ili kad bi dobili upitnik bilo bi dobro da imamo opciju da na određena pitanja ne moramo odgovoriti" (15S) 
Sudionici navode i da djeca pri sudjelovanju u istraživanjima ponekad pri odgovaranju na pitanja nisu posve iskrena. Sudionici su dali prijedloge istraživačima kako da dobiju iskrenije odgovore od djece. Navode da je važno da istraživači pokažu razumijevanje za mišljenja djece i mladih, da ih ne osuđuju, da se koriste uzori koji govore istinu te da se koristi neka vrsta nagrade za sudjelovanje.

„Važno je da pokažu razumijevanje za ono što iznosimo"(2S)

"Bili bi iskreniji kada bi vidjeli da je naše mišljenje važno"(5S)

"Kada nas ne osuđuju i kada pokažu razumijevanje"(11S)

"Netko bi trebao razbiti led, kada bi netko počeo govoriti što zaista misli onda bi ga i ostali slijedili na taj način govoreći"(14S)

"Važno je da se ljudi poštuju pa je moguće prijeći prepreke"(11S)

"Pomoglo bi kada bi vidjeli da i ostali govore o stvarima koje su ozbiljne $i$ teške "(6S)

U pogledu zaštite podataka, navode da bi bilo dobro da odrasli ne budu prisutni tijekom intervjua.

"Roditelji ne bi trebali biti prisutni", (9S)

"Apsolutno se ne slažemo da budu prisutni roditelji jer bi mi bili pod pritiskom" (4S)

Prijedlozi za zaštitu privatnosti koju navode djeca su: razgovarati samo s jednom osobom, koristiti metodu papir-olovka, imati mogućnost preskočiti neka pitanja, pokazati razumijevanje za mišljenje djece, ne prosuđivati, te pokazati suosjećanje prema djeci.

Zaključno, vezano uz prikupljanje podataka, sudionici misle da su neka pitanja toliko privatna da se ne bi trebala niti postavljati djeci i mladima u istraživanjima a predlažu i da roditelji ne budu prisutni uz njih za vrijeme istraživanja.

\section{RASPRAVA}

U okviru projekta razvoja kohortnog longitudinalnog istraživanja (ECDP) EuroCohort, provedeno je kvalitativno istraživanje sa savjetodavnom grupom djece i mladih u kojem se željelo iz dječje perspektive sagledati mogućnosti istraživanja dobrobiti djece uzevši u obzir etička načela o sudjelovanju djece u istraživanjima. Rezultati prikupljenih podataka govore o slaganju sudionika o tome što je za njih dobrobit i važnosti koju pridaju pojedinim područjima dobrobiti i šire dimenzijama dobrobiti. Djeca i mladi dobrobit povezuju s pozitivnim događajima iz vlastitog života odnosno definiraju dobrobit kroz ono što njih čini sretnima zatim s odnosima s roditeljima, braćom i sestrama, vršnjacima, nastavnicima. Djeca 
navode da je za njih dobrobit, sreća i zadovoljstvo odnosno kada imaju dobre odnose s prijateljima i roditeljima. Izjave djece kao i procjene u kvantitativnom dijelu radionica podudaraju se u važnosti pojedinih područja dobrobiti i dimenzija dobrobiti u smjeru naglašavanja važnosti obitelji i prijatelja, škole i zdravlja za njihovu dobrobit. Kao glavne domene dobrobiti djece navode: odnose kod kuće, odnose s braćom i sestrama, školu, slobodno vrijeme, prijatelje.

Slični nalazi dobiveni su i u drugim kvalitativnim istraživanjima o dobrobiti s djecom i mladima u Hrvatskoj (Tadić-Vujčić i sur, 2019) te u drugim zemljama (Fattore i sur., 2012) kao i u kvantitativnim istraživanjima dobrobiti djece (npr. Casas i sur., 2017; González-Carrasco i sur, 2017; Huebner, 2004; Shek, 2015). U istraživanju Tadić Vujčić i suradnika (2019) djeca navode da za njih dobrobit, sreća i zadovoljstvo znači da imaju dobre odnose s prijateljima i roditeljima, da su zadovoljni školom, da mogu koristiti slobodno vrijeme i ostvarivati zacrtane planove i ciljeve. Izvor pozitivnih osjećaja je odsutnost stresa, provođenje vremena s prijateljima i mogućnost korištenja slobodnog vremena dok računala i mobitele te nedostatak vremena djeca vide kao glavnu prepreku u ostvarivanju sreće koja proizlazi iz korištenja slobodnog vremena. Djeci u prvom redu učitelji, roditelji i prijatelji pružaju podršku u životu, dok školu i manjak samopouzdanja vide kao nešto što im može otežati postizanje ciljeva u životu. U istom istraživanju se pokazalo da se s razvojem djece mijenja i važnost pojedinih domena dobrobiti o kojima djeca izvještavaju što ukazuje i na važnost longitudinalnih istraživanja dobrobiti. Longitudinalni nacrti istraživanja dobrobiti omogućavaju formiranje pouzdanijih spoznaja o promatranim razvojnim promjenama, te varijablama koje utječu na dobrobit tijekom vremena. Nadalje, domene dobrobiti koje navode djeca i mladi vezane su uz zaštitne i rizične faktore razvoja djece i to prvenstveno povezane s obitelji. Upravo su se obiteljska otpornost i obiteljska dobrobit u kvantitativnim istraživanjima pokazale važnim čimbenicima dječje dobrobiti (Lawler i sur., 2017; Newland, 2015; Walsh, 2013). S druge strane, rizični obiteljski čimbenici povezani s dobrobiti već u predškolsko doba nalaze se u uvjetima života obitelji i izvorima podrške koja je obiteljima na raspolaganju (Šućur i sur., 2015).

Vezano uz etičke dileme oko dobivanja pristanka za sudjelovanje u istraživanju te važnost zaštite podataka i privatnosti djece u istraživanjima utvrđeno je da djeca razumiju važnost osobnog pristanka te se slažu da istraživači trebaju pitati roditelje o sudjelovanju njihovog djeteta u istraživanju. Ujedno u pogledu prikupljanja podataka, djeca misle da su neka pitanja toliko privatna da se ne bi trebala niti postavljati, a predlažu i da roditelji ne budu prisutni uz njih za vrijeme istraživanja. 
Novija istraživanja pokazuju da je moguće dobiti pouzdane i valjane podatke o dobrobiti od djece već u dobi od 8 godina (Ben-Arieh i sur., 2014; Franc i sur. 2018). Ovo kvalitativno istraživanje potvrđuje te nalaze za djecu od 10 godina. Izazov je u kvalitativnim istraživanjima uspostaviti ravnotežu te čuvati vjerodostojnost i dosljednost koja je povezana s tri neovisna, ali ipak povezana obilježja, a to su: rigoroznost postupaka i metoda prikupljanja podataka visoke kvalitete koji su pažljivo analizirani, vjerodostojnost istraživača koja ovisi o izobrazbi, iskustvu, načinu vođenja bilješki o istraživačkom radu, i poštivanje kvalitativne metode, induktivne analize i holističkog razmišljanja (Ajduković, 2014). Dobiveni nalazi u ovom istraživanju ukazuju da djeca i mladi mogu biti aktivni sudionici istraživanja, da ih se treba pitati te da mogu dati vrijedne informacije za provođenje posebno longitudinalnih istraživanja dobrobiti te ukazuju na važnost rasprave s djecom i mladima o etičkim pitanjima za unaprjeđenje istraživanja. $\mathrm{O}$ važnosti informiranja djece i mladih o etičkim pitanjima u istraživanjima govori i istraživanje Audrey i suradnici (2016.). Naime u ispitivanju stajališta mladih o svrsi i sastavu odbora za etiku u istraživanjima, od 48 mladih u dobi od 17 do 19 godina iz Velike Britanije većina je imala malo ili nikakvo specifično znanje o etičkim odborima kao važnim akterima u prezentiranju istraživačkog nacrta i praćenju istraživanja. Ako se uzme da su djeca stručnjaci za djetinjstvo, što novija istraživanja govore, važno je kako se istraživači prema njima odnose. Istraživači trebaju biti refleksivni te se propitkivati kako djeca doživljavaju istraživanje te što može utjecati na djecu, aktivne sudionike u istraživanjima. Glavna poruka jednog istraživanja o aktivnom sudjelovanju u istraživanjima je da je istraživačima potrebna podrška i trening kako djecu uključiti kao aktivne sudionike te da etički odbori kod procjenjivanja projekata trebaju to uzeti u obzir (Spriggs i Gillam, 2019). Stoga se može zaključiti da je u budućim istraživanjima svakako potrebno informirati djecu i mlade o svim etapama istraživanja te ih aktivno uključiti u donošenje odluka o nacrtima i provođenju istraživanja.

Kao preporuke koje se mogu izvesti iz ovog istraživanja treba istaknuti važnost rada na odnosima djece s roditeljima, učiteljima, prijateljima, važnost dvosmjerne komunikacije djece i odraslih, posebno roditelja. Zatim osnaživati kvalitetu života u školi, raditi s djecom i mladima na samopouzdanju. Poseban dio preporuka koje se mogu izvesti iz dobivenih rezultata su važnost uvažavanja mišljenja djece i mladih, poštivanje prava djece i mladih da daju svoj glas u odlukama koje ih se tiču, poštivanje privatnosti djece i mladih, kao i aktivno uključivanje djece i mladih u sve faze istraživačkog projekta o dobrobiti. Ovo istraživanje također omogućava stjecanje praktičnih iskustava i novih spoznaja vezanih uz uspostavu nacionalnog okvira za longitudinalno praćenje djece u Hrvatskoj, što 
je prema stručnjacima jedan od važnih zadataka psihološke struke (Kaliterna-Lipovčan, Brajša-Žganec i Dević, 2017), ali i nacionalnih politika vezanih uz djecu i mlade poput Nacionalne strategije za prava djece u Republici Hrvatskoj za razdoblje od 2014. do 2020. godine (Vlada Republike Hrvatske, 2014).

\section{ZAKLUČAK}

Iz prikazanih rezultata kvalitativnog istraživanja o tome kako djeca doživljavaju različite aspekte dobrobiti, što smatraju najvažnijim čimbenicima koji utječu na njihovu dobrobit, te koja ih etička pitanja u provođenju longitudinalnih istraživanja s djecom najviše brinu može se zaključiti da dobrobit za sudionike savjetodavne skupine ECDP projekta znači imati dobre odnose $s$ vršnjacima, prijateljima i roditeljima, te zadovoljstvo školom. Najvažnije domene dobrobiti za njih su: obitelj, prijatelji, škola te posebno odnosi s roditeljima, prijateljima i nastavnicima. Po pitanju provođenja longitudinalnih istraživanja s djecom može se zaključiti da djeca razumiju važnost osobnog pristanka te se slažu da istraživači trebaju pitati roditelje o sudjelovanju njihovog djeteta u istraživanju. Nadalje, što se tiče prikupljanja podataka, djeca misle da su neka pitanja toliko privatna da se ne bi trebala niti postavljati a predlažu i da roditelji ne budu prisutni uz njih za vrijeme istraživanja. Na kraju možemo iz svega zaključiti da je iznimno važno i korisno djecu i mlade uključiti kao aktivne sudionike u planiranje i provođenje jednog longitudinalnog istraživanja dobrobiti djece i mladih kao što je EuroCohort projekt.

\section{LITERATURA}

1/ AJDUKOVIĆ, M. (2014). „Kako izvještavati o kvalitativnim istraživanjima? Smjernice za istraživače, mentore i recenzente." Ljetopis socijalnog rada 2014., 21 (3), str. 345-366.

2/ AJDUKOVIĆ, M. I KOLESARIĆ, V. (Ur.). (2003). „Etički kodeks istraživanja s djecom." Zagreb, HR: Državni zavod za zaštitu obitelji, materinstva i mladeži.

3/ AUDREY, S., BROWN, L., CAMPBELL, R., BOYD, A. I MACLEOD, I. (2016). Young people's views about the purpose and composition of research ethics committees: findings from the PEARL qualitative study. BMC Med Ethics; 17(1): 53. Published online 2016 Sep 2. doi: 10.1186/s12910-016-0133-1.

4/ BEN-ARIEH, A., CASAS, F., FRØNES, I., I KORBIN, J. E. (2014). „Multifaceted concept of child well-being." U A. Ben-Arieh, F. Casas, I. Frønes, i J. E. Korbin (Ur.), Handbook of child well-being (str. 1-27). Dordrecht, The Netherlands: Springer. https://doi.org/10.1007/978-90-481-9063-8_134. 
5/ BRADFORD, R., RUTHERFORD, D. L., I JOHN, A. (2002). „Quality of life in young people: ratings and factor structure of the Quality of Life Profile-Adolescent Version." Journal of adolescence, 25(3), 261-274. https://doi.org/10.1006/ jado.2002.0469.

6/ BRADSHAW, J., HOELSCHER, P., I RICHARDSON, D. (2007). „An index of child well-being in the European Union. Social Indicators Research“, 80(1), 133177. https://doi.org/10.1007/s11205-006-9024-z.

7/ CASAS, F., GONZÁLEZ, M., NAVARRO, D. I ALIGUÉ, M. (2013). „Children as advisers of their researchers: Assuming a different status for children; Child Indicators Research", 6, 2, 193-212 doi 10.1007/s12187-012-9168-0.

8/ CASAS, F., FIGUER, C., GONZÁLEZ, M., MALO, S., ALSINET, C., I SUBARROCA, S. (2007). „The well-being of 12-to 16-year-old adolescents and their parents: Results from 1999 to 2003 Spanish samples". Social Indicators Research, 83(1), 87-115. https://doi.org/10.1007/s11205-006-9059-1.

9/ CASAS, F., I GONZÁLEZ-CARRASCO, M. (2018). „Subjective well-being decreasing with age: New research on children over 8. Child Development", 90(2), 375-394. doi:10.1111/cdev.13133.

10/ COYNE, I. (2010). „Accessing children as research participants: Examining the role of gatekeepers. Child: Care, Health and Development", 36(4), 452-454.

11/ DIENER, E. (2012). „New findings and future directions for subjective well-being research. American Psychologist“, 67(8), 590-597. doi:10.1037/a0029541

12/ DIENER, E. (2013). „The Remarkable Changes in the Science of Subjective Well-Being. Perspectives on Psychological Science", 8(6), 663-666. doi:10.1177/1745691613507583.

13/ DINISMAN, T., FERNANDES, L. I MAIN, G. (2015). „Findings from the first wave of the ISCWeB project: International perspectives on child subjective well-being. Child Indicators Research“, 8(1), 1-4.

14/ FATTORE, T.,MASON, J. I WATSON, E. (2012). „Locating the child centrally as subject in research: Towards a child interpretation of well-being. Child Indicators Research", 5(3), 423-435.

15/ FRANC, R., SUČIĆ I., BABAROVIĆ T., BRAJŠA-ŽGANEC A., KALITERNA-LIPOVČAN L. I DEVIĆ I. (2018). „How to Develop Well-Being Survey Questions for Young Children: Lessons Learned from Cross-Cultural Cognitive Interviews." U: Pollock G., Ozan J., Goswami H., Rees G., i Stasulane A. (Ur.), Measuring Youth Well-being. Cham: Springer International Publishing AG. https://doi. org/10.1007/978-3-319-76063-6_6.

16/ GALE, N. K., HEATH, G., CAMERON, E., RASHID, S. I REDWOOD, S. (2013). "Using the framework method for the analysis of qualitative data in multidisciplinary health research. BMC Medical Research Methodology", 13(1), 117. https://doi.org/10.1186/1471-2288-13-117. 
17/ GONZÁLEZ-CARRASCO, M., CASAS, F., MALO, S., VIÑAS, F., I DINISMAN, T. (2017). „Changes with age in subjective well-being through the adolescent years: Differences by gender. Journal of Happiness studies", 18(1), 63-88. https://doi.org/10.1007/s10902-016-9717-1.

18/ HART, R. (1992). „Children's participation from tokenism to citizenship. Florence: UNICEF Innocenti Research Centre." Preuzeto s http://www.unicefirc.org/publications/pdf/childrens_participation.pdf. (15.07. 2019.).

19/ HRVATSKA PSIHOLOŠKA KOMORA (2004). „Kodeks etike psihološke djelatnosti." Zagreb.

20/ HUEBNER, E. S. (1991a). "Correlates of life satisfaction in children. School psychology quarterly", 6(2), 103. http://dx.doi.org/10.1037/h0088805.

21/ HUEBNER, E. S. (2004). „Research on assessment of life satisfaction of children and adolescents. Social indicators research", 66(1-2), 3-33. https://doi. org/10.1023/B:SOCI.0000007497.57754.e3.

22/ HUEBNER, E.S., DRANE, J.W. I VALOIS, R.F. (2000). „Levels and demographic correlates of adolescent life satisfaction reports. School Psychology International", 21(3). 281-292. https://doi.org/10.1177/0143034300213005.

23/ JEĐUD BORIĆ, I., MIROSAVLJEVIĆ, A. I ŠALINOVIĆ; M.(Ed.) (2017). „Respect, involve, accept. Child participation in the Republic of Croatia - situation analysis"; Zagreb: UNICEF Office for Croatia.

24/ JOHNSON, V., HART, R. I COLWELL, J. (Ed.) (2014). „Steps to engaging young children in research. Brighton: Education Research Centre, University of Brighton" Preuzeto s: http://www.bernardvanleer.org/steps-to-engagingyoung-children-in-research (02.09.2019).

25/ KALITERNA, LJ., BRAJŠA-ŽGANEC, A., I DEVIĆ, I. (2017.). „Croatian expert's opinion about measuring well-being of children and young people - results of the Delphi survey." U: Burić, I. (Ur.) Book of Selected Proceedings of 20th Psychology Days in Zadar. (str. 69-80). Zadar: Sveučilište u Zadru.

26/ LAWLER, M. J., NEWLAND, L. A., GIGER, J. T., ROH, S., I BROCKEVELT, B. L. (2017). „Ecological, relationship-based model of children's subjective wellbeing: Perspectives of 10-year-old children in the United States and 10 other countries." Child Indicators Research, 10(1), 1-18. https://doi.org/10.1007/ s12187-016-9376-0.

27/ MILAS, G. (2005). „Istraživačke metode u psihologiji i drugim društvenim znanostima." Jastrebarsko: Slap.

28/ MOORE, K. A., MURPHEY, D., BELTZ, M., MARTIN, M. C., BARTLETT, J., I CAAL, S. (2016). "Child wellbeing: Constructs to measure child well-being and risk and protective factors that affect the development of young children." Preuzeto s: www.childtrends.org/publications/child-well-constructs-measure-childwellrisk-protective-factors-affect-development-young-children. (05.09.2019). 
29/ NAVARRO, D., MONTSERRAT, C., MALO, S., GONZÁLEZ, M., CASAS, F. I CROUS, G. (2017). „Subjective well-being: what do adolescents say?. Child and Family SocialWork“; 22,1, 175-184. doi:10.1111/cfs.12215.

30/ NEWLAND, L. A. (2015). „Family well-being, parenting, and child well-being: Pathways to healthy adjustment." Clinical Psychologist, 19(1), 3-14. http:// dx.doi.org/10.1111/cp.12059.

31/ OZAN, J., POLLOCK, G., GOSWAMI, H., I LYNN, P. (2018). „Challenges in Conducting a New Longitudinal Study on Children and Young People Well-Being in the European Union." U: Pollock G., Ozan J., Goswami H., Rees G., i Stasulane A. (Ur.), Measuring Youth Well-being. Cham: Springer International Publishing AG. https://doi.org/10.1007/978-3-319-76063-6_6.

32/ PARK, N. I HUEBNER, E. S. (2005). „A cross-cultural study of the levels and correlates of life satisfaction among adolescents." Journal of Cross-Cultural Psychology, 36, 444-456. https://doi.org/10.1177/0022022105275961.

33/ PROCTOR, C., ALEX LINLEY, P. I MALTBY, J. (2009). „Youth life satisfaction measures: A review." The Journal of Positive Psychology, 4(2), 128-144. https:// doi.org/10.1080/17439760802650816.

34/ RABIEE, F. (2004). „Focus-group interview and data analysis.“ Proceedings of the Nutrition Society, 63(04), 655-660.

35/ RICHARDSON, D. I ALI, N. (2014). „An evaluation of international surveys of children OECD Social“, Employment and Migration Working Papers (Vol. 46). Paris: OECD Publishing.

36/ RITCHIE, J. I LEWIS, J. (2003). „Qualitative research practice: A guide for social science students and researchers." London: Sage Publications Inc.

37/ SHAW, C., BRADY, L., \& DAVEY, C. (2011). „Guidelines for research with children and young people." London: National Children's Bureau.

38/ SHEK D.T. (2005). „Economic Stress, Emotional Quality of Life, and Problem Behavior in Chinese Adolescents with and without Economic Disadvantage.“ U: Shek D.T., Chan Y.K., i Lee P.S. (Ur.) „Quality-of-Life Research in Chinese," Western and Global Contexts. Social Indicators Research Series, vol 25. Springer, Dordrecht. https://doi.org/10.1007/1-4020-3602-7_12.

39/ SKÅNFORS, L. (2009). „Ethics in child research: Children's agency and researchers^ethical radar'. Childhoods Today“, 3(1).

40/ SPRIGGS, M. I GILLAM, L. (2019). „Ethical complexities in child co-research.“ Research Ethics, 15(1), 1-16. doi: 10.1177/1747016117750207.

41/ SULDO, S. M. I HUEBNER, E. S. (2004a). „Does life satisfaction moderate the effects of stressful life events on psychopathological behavior during adolescence? School Psychology Quarterly“, 19(2), 93. doi: 10.1521/ scpq.19.2.93.33313. 
42/ SULDO, S. M. I HUEBNER, E. S. (2004b). „The Role of Life Satisfaction in the Relationship between Authoritative Parenting Dimensions and Adolescent Problem Behavior." Social Indicators Research, 66(1-2), 165-195. http:// dx.doi.org/10.1023/B:SOCI.0000007498.62080.1e.

43/ ŠUĆUR, Z., KLETEČKI RADOVIĆ, M., DRUŽIĆ LJUBOTINA, O. I BABIĆ, Z. (2015). „Siromaštvo i dobrobit djece predškolske dobi u Republici Hrvatskoj." Zagreb: Unicef - ured za Hrvatsku.

44/ TADIĆ VUJČIĆ, M., BRAJŠA-ŽGANEC, A. I FRANC, R. (2019). „Children and Young Peoples' Views on Well-Being: A Qualitative Study." Child Indicators Research, 12, 791-819. https://doi.org/10.1007/s12187-018-9559-y.

45/ VLADA REPUBLIKE HRVATSKE (2014). „Nacionalna strategija za prava djece u Republici Hrvatskoj za razdoblje od 2014. do 2020. godine." Preuzeto s: https://vlada.gov.hr/pristup-informacijama/programi-strategije-planovi-iizvjesca/strateski-dokumenti-vlade-rh/ministarstvo-za-demografiju-obiteljmlade-i-socijalnu-politiku/17700 (07.09.2019).

46/ WALSH, F. (2003). „Family resilience: A framework for clinical practice. Family Process", 42(1), 1-18. https://doi.org/10.1111/j.1545-5300.2003.00001.x.

\section{SAŽETAK \\ SUDJELOVANJE DJECE I MLADIH U ISTRAŽIVANJU DOBROBITI: KVALITATIVNA ANALIZA}

Cilj projekta Razvoja kohortnog longitudinalnog istraživanja (ECDP), financiranog u okviru OBZOR2020 programa Europske Komisije je razviti konkretne modele nove europske istraživačke infrastrukture za koordinaciju budućeg velikog europskog kohortnog 25 godišnjeg longitudinalnog istraživanja o dobrobiti djece i mladih. ECDP projekt usmjeren je na uspostavljanje uspješne istraživačke infrastrukture i budućeg EuroCohort istraživanja kroz: (a) razvijanje podrške među ključnim donositeljima politika te nacionalnim agencijama zaduženima za financiranje istraživačkih infrastruktura i anketnih prikupljanja podataka; (b) razvijanje znanstveno izvrsnog nacrta budućeg longitudinalnog anketnog istraživanja ; te (c) uspostavljanje stabilnog operativnog okvira koji jamči logističku opstojnost budućeg EuroCohort istraživanja. Cilj jedne dionice projekta je oformiti savjetodavnu grupu djece (CYPAG) te kroz fokusne grupe utvrditi dječju perspektivu o dobrobiti, što im znači riječ "dobrobit", što pod tim pojmom podrazumijevaju, kao i njihovo razumijevanje etičkih pitanja u longitudinalnim istraživanjima dobrobiti djece. S dvadesetak djece, starosti od 10 do 15 godina, predstavnicima 
različitih posebno angažiranih skupina djece u različitim područjima od tehničkih, sportskih do prirodoslovnih i društvenih, odnosno djece uključene u nacionalne i lokalne relevantne organizacije, djece iz vijeća učenika, djece iz dječjeg gradskog vijeća, djece iz relevantnih nevladinih organizacija, te djece uključene u sportske organizacije, održane su tri fokusne grupe. Dio djece pripada skupinama kao što su: djeca iz manjinskih skupina, djeca rastavljenih roditelja, djeca iz jednoroditeljskih obitelji, djeca iz udomiteljskih obitelji, djeca s poteškoćama, djeca s kroničnim bolestima, te djeca koja žive u siromaštvu. Prikazani su rezultati kvalitativnog istraživanja o tome kako djeca doživljavaju različite aspekte dobrobiti i što smatraju najvažnijim čimbenicima koji utječu na njihovu dobrobit, kako bi se prema njihovom mišljenju trebala izvoditi longitudinalna istraživanja dobrobiti djece te kako uključiti djecu u longitudinalna istraživanja dobrobiti, koja ih etička pitanja u provođenju longitudinalnih istraživanja s djecom najviše brinu i kako bi ih oni riješili. Dobiveni rezultati pokazuju da djeca i mladi svojim razumijevanjem dobrobiti te načinom naglašavanja važnosti vođenja računa o privatnosti i pravima djece i mladih kao sudionika znanstvenih istraživanja mogu značajno doprinijeti kvaliteti istraživanja dobrobiti, stoga ih je iznimno važno i korisno uključiti aktivno u planiranje i provođenje longitudinalnog istraživanja dobrobiti djece i mladih.

Ključne riječi: dobrobit; djeca i mladi; kvalitativno istraživanje; etička pitanja.

\section{SUMMARY}

\section{PARTICIPATION OF CHILDREN AND YOUNG PEOPLE IN WELL-BEING RESEARCH: A QUALITATIVE ANALYSIS}

The European Cohort Development Project (ECDP) is financed from the European Union's Horizon 2020 programme to create specific models for a European Research Infrastructure that will provide, over the next 25 years, comparative longitudinal survey data on child and young adult well-being. The infrastructure developed by ECDP will subsequently coordinate the first Europe wide cohort survey, named EuroCohort. This will be achieved through the following three objectives: (a) building support from key political policymakers with a brief which covers child well-being as well as national funding agencies tasked with infrastructural spending on science and survey data collection; (b) developing a scientifically excellent research design; (c) establishing a robust operation- 
al framework that will ensure the logistic integrity of EuroCohort. The aim of one section of the project is to set up a Children and Young People's Advisory Groups (CYPAG) and to identify, through focus groups, a children's perspective on well-being, examine the meaning of the word 'well-being', as well as gather information of their understanding of ethical issues in longitudinal research on child well-being. Three focus group were conducted with about 20 children, in the age between 10 and 15, representatives from various fields of specially engaged groups of children, including technical, sports, science and social field, children involved in national and local relevant organizations, children from student councils, children from children's city council, children from relevant nongovernmental organizations and also children involved in sports organizations. Some of the children belong to groups such as minorities, children of divorced parents, children from single-parent families, children from foster families, children with disabilities, children with chronic illnesses, and children living in poverty. The results of a qualitative study are presented on how children experience different aspects of well-being, what they consider to be the most important factors affecting their well-being, how in their opinion longitudinal studies of child well-being should be conducted, how to include children in longitudinal studies of well-being, what ethical issues are they most concerned with within longitudinal research with children and how they can be addressed. The results show that children and young people, through their understanding of well-being and by emphasizing the importance of taking into account the privacy and rights of children and young people as participants in scientific research, can significantly contribute to the quality of well-being research, so it is extremely important and useful to involve them actively in planning and conducting a longitudinal study of the well-being of children and young people.

Key Words: well-being; children and young people; qualitative research; ethical issues. 